\title{
Short communication: Prediction of intake in dairy cows under tropical conditions
}

\author{
M. C. Souza, ${ }^{\star}$ A. S. Oliveira, ${ }^{* 1}$ C. V. Araújo, ${ }^{*}$ A. F. Brito,† R. M. A. Teixeira,‡ E. H. B. K. Moares, ${ }^{*}$ \\ and D. C. Moura* \\ *Instituto de Ciências Agrárias e Ambientais, Universidade Federal de Mato Grosso - Campus Sinop, 78557-267 Sinop, MT, Brazil \\ †University of New Hampshire, Department of Biological Sciences, Durham 03824 \\ łInstituto Federal de Educação, Ciência e Tecnologia do Triângulo Mineiro, 38064-790 Uberaba, MG, Brazil
}

\section{ABSTRACT}

A meta-analysis was conducted to develop a model for predicting dry matter intake (DMI) in dairy cows under the tropical conditions of Brazil and to assess its adequacy compared with 5 currently available DMI prediction models: Agricultural and Food Research Council (AFRC); National Research Council (NRC); Cornell Net Carbohydrate and Protein System (CNCPS; version 6); and 2 other Brazilian models. The data set was created using 457 observations $(\mathrm{n}=1,655$ cows) from 100 studies, and it was randomly divided into 2 subsets for statistical analysis. The first subset was used to develop a DMI prediction equation (60 studies; 309 treatment means) and the second subset was used to assess the adequacy of DMI predictive models (40 studies; 148 treatment means). The DMI prediction model proposed in the current study was developed using a nonlinear mixed model analysis after reparameterizing the NRC equation but including study as a random effect in the model. Body weight $($ mean $=540 \pm 57.6 \mathrm{~kg}), 4 \%$ fatcorrected milk $($ mean $=21.3 \pm 7.7 \mathrm{~kg} / \mathrm{d})$, and days in milk (mean $=110 \pm 62 \mathrm{~d}$ ) were used as independent variables in the model. The adequacy of the DMI prediction models was evaluated based on coefficient of determination, mean square prediction error (MSPE), root MSPE (RMSPE), and concordance correlation coefficient (CCC). The observed DMI obtained from the data set used to evaluate the prediction models averaged $17.6 \pm 3.2 \mathrm{~kg} / \mathrm{d}$. The following model was proposed: DMI $(\mathrm{kg} / \mathrm{d})=[0.4762( \pm 0.0358) \times 4 \%$ fatcorrected milk $+0.07219( \pm 0.00605) \times$ body weight $\left.{ }^{0.75}\right]$ $\times\left(1-e^{-0.03202( \pm 0.00615) \times[\text { days in milk }+24.9576( \pm 5.909)]}\right)$. This model explained $93.0 \%$ of the variation in DMI, predicting it with the lowest mean bias $(0.11 \mathrm{~kg} / \mathrm{d})$ and RMSPE (4.9\% of the observed DMI) and the highest precision [correlation coefficient estimate $(\rho)=0.97$ ]

Received October 29, 2013.

Accepted January 2, 2014.

${ }^{1}$ Corresponding author: andresoli@ufmt.br and accuracy [bias correction factor $\left(C_{\mathrm{b}}\right)=0.99$ ]. The NRC model prediction equation explained $92.0 \%$ of the variation in DMI and had the second lowest mean bias $(0.42 \mathrm{~kg} / \mathrm{d})$ and RMSPE $(5.8 \%$ of the observed DMI), as well as the second highest precision $(\rho=0.94)$ and accuracy $\left(C_{\mathrm{b}}=0.98\right)$. The CNCPS and AFRC DMI prediction models explained 93.0 and $85.0 \%$ of the variation in DMI but underpredicted DMI by 1.8 and $1.4 \mathrm{~kg} / \mathrm{d}$, respectively. These 2 models (CNCPS and AFRC) resulted, respectively, in RMSPE of 11.3 and $10.7 \%$ of the observed DMI, with moderate to high precision $(\rho=0.81$ and 0.82$)$ and accuracy $\left(C_{\mathrm{b}}=0.84\right.$ and $0.89)$. The remaining 2 models resulted in the poorest results, underpredicting DMI by 2.3 and $1.9 \mathrm{~kg} / \mathrm{d}$, with RMSPE of 22.8 and $14.9 \%$ of the observed DMI and moderate to low precision $(\rho=0.49$ and 0.76$)$ and accuracy $\left(C_{\mathrm{b}}=0.81\right.$ and 0.86$)$. The new model derived from the current meta-analytical approach provided the best accuracy and precision for predicting DMI in lactating dairy cows under Brazilian conditions.

Key words: meta-analysis, modeling, prediction of feed intake

\section{Short Communication}

Accurate prediction of feed intake by dairy cows is essential for optimizing nutrient utilization in dairy diets, which can potentially increase the productive, economic, and environmental performance of dairy systems. Despite the complexity of the mechanisms regulating feed intake, several currently available models [e.g., Agricultural and Food Research Council (AFRC, 1993); NRC, 2001; Freitas et al., 2006; Cornell Net Carbohydrate and Protein System (CNCPS, version 6.0; Tylutki et al., 2008); Santos et al., 2009] use empirical approaches to predict DMI with animal-related variables such as BW, milk production and composition, and DIM as fixed effects in the models. It is important to note, however, that application of empirical models is population-dependent, thus restricting their use to specific environmental and geographical conditions. 
Table 1. Selected models for predicting DMI $(\mathrm{kg} / \mathrm{d})$ in lactating dairy cows

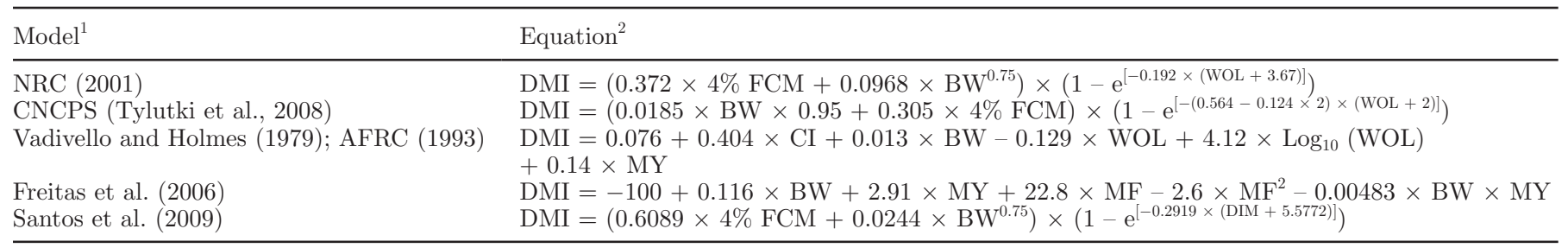

${ }^{1}$ CNCPS $=$ Cornell Net Carbohydrate and Protein System; AFRC = Agriculture and Food Research Council.

${ }^{2} \mathrm{WOL}=$ week of lactation; $\mathrm{CI}=$ concentrate intake $(\mathrm{kg}$ of $\mathrm{DM} / \mathrm{d}) ; \mathrm{MY}=$ milk yield $(\mathrm{kg} / \mathrm{d}) ; \mathrm{MF}=$ milk fat $(\%)$.

Therefore, we hypothesized that models constructed with observations obtained under conditions different from those commonly found in tropical environments may lack the accuracy and precision to predict DMI.

The objectives of the current study were (1) to develop a model to predict DMI in lactating dairy cows under Brazilian conditions with BW, milk production and composition, and DIM as independent variables in the model, and (2) to evaluate and compare the adequacy of the proposed model with 5 currently available DMI prediction models: 2 American-based: NRC (2001) and Cornell Net Carbohydrate and Protein System (CNCPS, version 6.0; Tylutki et al., 2008); 1 British-based: AFRC (1993); and 2 Brazilian-based: Freitas et al. (2006) and Santos et al. (2009), using an independent data set.

The data set used in the current study was built from observations reported in 100 studies (457 treatments means; 1,655 cows) published in Brazilian journals from 1991 to 2013 (76 studies) or reported in graduate student theses (24 studies). The criteria adopted for data inclusion in the data set were as follows: (1) experiment conducted under the tropical conditions of Brazil; (2) cows under different feeding management systems and production levels; (3) individual measurements of DMI; (4) estimation of pasture intake using external and internal markers to determine fecal output of DM; and (5) adequate description of cows (e.g., BW, DIM, milk yield, and composition) and experimental diets (e.g., ingredient and chemical composition). Specifically, the data set was composed of Holstein cows (72.6\%) and Holstein $\times$ Zebu crosses $(27.4 \%)$ fed either TMR $(86 \%)$ or pasture (14\%). Forages used by TMR-fed cows included corn silage (75.5\%), sugarcane (12.7\%), spineless cactus (Opuntia ficus indica Mill.) or spineless cactus plus corn silage (6.3\%), sugarcane silage (1.4\%), sorghum and sunflower silages $(2.4 \%)$, and alfalfa silage or hay (1.7\%). Forages grazed by pasture-fed cows included Pennisetum purpureum Schum. (35.3\%), Brachiaria spp. (29.4\%), Panicum maximum (21.6\%), and Cynodon spp. (13.7\%).

For statistical analysis, the data set was randomly divided into 2 subsets, with the first subset (60 stud- ies; 309 treatments means; Appendix 1; development) used to develop a DMI prediction model and the second subset (40 studies; 148 treatments means; Appendix 2; evaluation) used to assess the adequacy of the new developed DMI prediction model compared with 5 currently available models (Table 1 ).

The DMI prediction model proposed herein was developed using a nonlinear mixed-model analysis of the reparameterized NRC (2001) model but including study as a random effect in the model. Specifically, the proposed nonlinear model was adjusted using metabolic BW $\left(\mathrm{BW}^{0.75}\right), 4 \% \mathrm{FCM}$, and DIM as fixed effects. Because the data set was built using observations from 60 studies with different breeds, feeding systems, environmental conditions, and experimental methodologies, it was necessary to quantify the variance associated with study, as well as to predict fixed effects adjusted for study effect. Therefore, each study in the data set was treated as a random sample from a larger population of studies (St-Pierre, 2001; Sauvant et al., 2008). Inclusion of study effects required estimation of both the fixed effects associated with the nonlinear model parameters and the random effects of study, similar to the approach described in Vyas and Erdman (2009). The nonlinear mixed (NLMIXED) procedure (Littell et al., 2006) of SAS (version 9.1; SAS Institute Inc., Cary, NC) was used to fit the model:

$Y_{i j}=\left(\beta_{1} \times B W_{i j}^{0.75}+\beta_{2} \times 4 \% F C M_{i j}\right) \times\left(1-e^{\left[-\beta_{3} \times\left(D I M_{i j}+\beta_{4}\right)\right]}\right)+e x p_{j}+e_{i j}$

where $Y_{i j}=\mathrm{DMI}$ of the ith DMI at the jth study with $i$ ranging from 1 to 309 , and $j$ ranging from 1 to $60,\left(\beta_{1}\right.$ $\left.\times B W_{i j}^{0.75}+\beta_{2} \times 4 \% F C M_{i j}\right) \times\left(1-e^{\left[-\beta_{3} \times\left(D I M_{i j}+\beta_{4}\right)\right]}\right)=$ fixed effect of model; $\beta_{1}$ and $\beta_{2}=$ coefficients representing the DMI per kilogram of $\mathrm{BW}^{0.75}$ and per kilogram of $4 \%$ FCM, respectively; $\beta_{3}$ and $\beta_{4}=$ coefficients representing the adjustment for DIM; $\exp _{j}=$ random effect of study assuming a normal distribution; and $e_{i j}=$ random error associated with each observation assuming a normal distribution. Data points were removed if the studentized residual was outside the range of -2.5 
Table 2. Descriptive statistics of the data set used to develop and evaluate models to predict DMI on dairy cows

\begin{tabular}{|c|c|c|c|c|c|}
\hline Item & Mean & Median & Maximum & Minimum & $\mathrm{SD}$ \\
\hline \multicolumn{6}{|l|}{ Development $(\mathrm{n}=309)^{1}$} \\
\hline Forage diet $(\%$ of $\mathrm{DM})$ & 59.4 & 60.0 & 100.0 & 35.0 & 13.6 \\
\hline NDF $\operatorname{diet}(\%$ of DM) & 41.1 & 40.4 & 78.8 & 26.9 & 10.3 \\
\hline $\mathrm{CP} \operatorname{diet}(\%$ of $\mathrm{DM})$ & 15.1 & 14.6 & 19.6 & 8.0 & 2.4 \\
\hline Ether extract ( $\%$ of DM) & 3.1 & 3.1 & 7.3 & 0.8 & 1.6 \\
\hline DMI $(\mathrm{kg} / \mathrm{d})$ & 16.3 & 15.8 & 25.3 & 3.2 & 3.7 \\
\hline Milk yield $(\mathrm{kg} / \mathrm{d})$ & 21.3 & 15.3 & 37.3 & 3.4 & 7.7 \\
\hline Milk fat $(\%)$ & 3.71 & 3.55 & 5.56 & 2.20 & 0.58 \\
\hline $4 \%$ FCM $(\mathrm{kg} / \mathrm{d})$ & 20.1 & 15.5 & 37.3 & 3.1 & 6.8 \\
\hline BW (kg) & 540.4 & 516.0 & 675.4 & 409.2 & 57.6 \\
\hline DIM & 110 & 140 & 304 & 7 & 62 \\
\hline \multicolumn{6}{|l|}{ Evaluation $(\mathrm{n}=148)^{2}$} \\
\hline Forage diet (\% of DM) & 60.0 & 59.4 & 100.0 & 40.0 & 13.2 \\
\hline NDF $\operatorname{diet}(\%$ of DM $)$ & 40.0 & 37.4 & 72.8 & 25.5 & 8.1 \\
\hline $\mathrm{CP} \operatorname{diet}(\%$ of $\mathrm{DM})$ & 15.6 & 16.0 & 19.6 & 8.5 & 2.5 \\
\hline Ether extract ( $\%$ of DM) & 3.5 & 2.8 & 7.5 & 1.3 & 1.6 \\
\hline DMI $(\mathrm{kg} / \mathrm{d})$ & 17.6 & 17.8 & 24.3 & 10.1 & 3.2 \\
\hline Milk yield $(\mathrm{kg} / \mathrm{d})$ & 23.1 & 24.5 & 35.6 & 8.4 & 7.3 \\
\hline Milk fat $(\%)$ & 3.46 & 3.50 & 4.58 & 2.25 & 0.50 \\
\hline $4 \%$ FCM $(\mathrm{kg} / \mathrm{d})$ & 21.0 & 22.7 & 31.3 & 7.9 & 6.3 \\
\hline BW $(\mathrm{kg})$ & 551.8 & 558.8 & 663.1 & 394.4 & 60.9 \\
\hline DIM & 121 & 120 & 230 & 7 & 55 \\
\hline
\end{tabular}

${ }^{1}$ Appendix 1.

${ }^{2}$ Appendix 2.

to 2.5 (Neter et al., 1996). The critical level of probability for type I error was set at $\alpha=0.05$.

The adequacy of the DMI predictive model developed in the present study and that of currently available models (Table 1) were assessed for precision and accuracy using graphic analysis, coefficient of determination, mean square prediction error (MSPE), root MSPE (RMSPE), and concordance correlation coefficient (CCC) analyses using the Model Evaluation System (College Station, TX; http://nutritionmodels. tamu.edu/mes.html) as described by Tedeschi (2006).

The RMSPE value was expressed relative to the observed mean. The MSPE comprises 3 sources of error expressed as percentage of MSPE: (1) the error due to bias, (2) the error due to deviation of the regression slope from 1, and (3) the random error. The random error represents the error that is not explained by the model (Bibby and Toutenburg, 1977). The precision and accuracy of the DMI prediction models were assessed by estimating the CCC, as described by Lin (1989). The CCC was divided into correlation coefficient $(\boldsymbol{\rho})$ or precision and bias correction factor $\left(\boldsymbol{C}_{\mathrm{b}}\right)$ or accuracy. The $\rho$ and $C_{\mathrm{b}}$ values ranges from 0 to 1 , with values closer to 1 indicating more precision and accuracy (Lin, 1989; King and Chinchilli, 2001; Liao, 2003). In addition, the Kolmogoroff-Smirnov D-test (Kolmogoroff, 1933; Smirnov, 1933) was used to assess the probability of whether or not 2 data sets (e.g., observed and predicted values) have same distribution.
The subsets used for developing and evaluating the DMI prediction models represented a wide range of dairy cow and diets characteristics. The descriptive statistics of cows and diets used in both subsets of data were similar, indicating that they were adequately randomized (Table 2). Moreover, the data set was representative of the dairy cattle systems commonly used in Brazil (Oliveira et al., 2007; Stock et al., 2007).

The fit model to predict DMI included $4 \%$ FCM, BW, and DIM as independent variables:

$$
\begin{gathered}
\text { DMI }(\mathrm{kg} / \mathrm{d})=[0.4762 \pm 0.0358(P<0.001) \\
\times 4 \% \mathrm{FCM}(\mathrm{kg} / \mathrm{d})+0.07219 \pm 0.00605(P<0.001) \\
\left.\times \mathrm{BW}(\mathrm{kg})^{0.75}\right] \times\left[1-e^{-0.03202 \pm 0.00615(P<0.001)}\right. \\
\times[\mathrm{DIM}+24.9576 \pm 5.909(P<0.001)]]
\end{gathered}
$$

An adjustment factor for DIM $\left[1-e^{-0.03202 \times(\text { DIM }+}\right.$ $\left.{ }^{24.9576)}\right]$ was included to improve the prediction of DMI during the first 120 DIM (Roseler et al., 1997). This adjustment was necessary during early lactation because the increase in DMI is slower than the increase in milk production in response to metabolic adaptations and gut fill in early lactation (Ingvartsen and Andersen, 2000). Based on the adjustment factor, it was estimated that DMI at the first week of lactation averaged $65 \%$ of that at 120 DIM when using fixed FCM and BW in the model predictions. 
Table 3. Summary of statistical measures to assess adequacy of several models using regression between observed (Y) and model-predicted (X) DMI

\begin{tabular}{|c|c|c|c|c|c|c|}
\hline Item $^{1}$ & \multicolumn{6}{|c|}{ Model } \\
\hline $\mathrm{X}(\mathrm{kg})$ & 17.72 & 18.02 & 15.84 & 16.20 & 15.30 & 15.73 \\
\hline Mean bias $(\mathrm{Y}-\mathrm{X})(\mathrm{kg})$ & -0.11 & -0.42 & 1.77 & 1.40 & 2.31 & 1.88 \\
\hline Coefficient of determination $\left(\mathrm{R}^{2}\right)$ & 0.93 & 0.92 & 0.93 & 0.85 & 0.37 & 0.78 \\
\hline \multicolumn{7}{|l|}{ Partition of MSPE (\%) } \\
\hline Error due to mean bias & 1.64 & 16.63 & 78.50 & 55.98 & 33.31 & 51.91 \\
\hline Error due to slope not equal to 1 & 3.63 & 3.21 & 3.95 & 0.98 & 26.89 & 15.97 \\
\hline Random error & 94.73 & 80.16 & 17.55 & 43.05 & 39.80 & 32.12 \\
\hline CCC (0 and 1$)$ & 0.964 & 0.930 & 0.674 & 0.733 & 0.400 & 0.656 \\
\hline$\rho(0$ and 1$)$ & 0.965 & 0.944 & 0.806 & 0.822 & 0.494 & 0.762 \\
\hline$C_{\mathrm{b}}(0$ and 1$)$ & 0.999 & 0.985 & 0.836 & 0.891 & 0.810 & 0.861 \\
\hline
\end{tabular}

${ }^{1} \mathrm{MSPE}=$ mean squared prediction error; $\mathrm{CCC}=$ concordance correlation coefficient; $\rho=$ correlation coefficient estimate $\left(\right.$ precision); $C_{\mathrm{b}}=$ bias correction factor (accuracy).

${ }^{2}$ Cornell Net Carbohydrate and Protein System (CNPCS) model.

${ }^{3} \mathrm{KS}=$ Kolmogoroff-Smirnov D-test (Kolmogoroff, 1933; Smirnov, 1933), which assesses the probability that 2 data sets (observed and modelpredicted values) have the same distribution.

The DMI prediction model proposed in the present study was also adjusted for the effect of study. Consequently, the potential effects of breed (i.e., Holstein vs. Holstein $\times$ Zebu cows) and feeding systems (i.e., TMR vs. pasture) on DMI among studies were accounted for in the model predictions (St-Pierre, 2001; Sauvant et al., 2008), thus explaining the selection of a single DMI prediction model. The chemical composition of diets was not included as an independent variable in the present model because, according to NRC (2001), the most common approach for formulating dairy cattle diets is to establish nutrient requirements first, followed by estimation of DMI, before considering the inclusion of dietary ingredients. Furthermore, equations containing dietary factors are best used to predict animal performance rather than feed intake (NRC, 2001).

It is well established that heat stress negatively affects the performance of lactating dairy cows (West, 2003). For instance, when environmental conditions are outside the thermal neutral zone due to increased air temperature and temperature-humidity index, DMI, milk yield, and feed efficiency all decrease substantially (West, 2003). Thus, adjustment for environmental conditions is needed to predict DMI (NRC, 2001). However, because of the insufficient environmental data reported in the studies selected for the current meta-analysis, climate variables (e.g., air temperature, temperaturehumidity index) were not used as fixed effects in the model.
A positive relationship $(P<0.001)$ between DMI and FCM $(0.476 \pm 0.036 \mathrm{~kg} / \mathrm{kg}$ of FCM) was observed (see proposed equation), due to increased energy demand for milk production. According to the NRC (2001), it is not conclusive whether milk production is driven by intake or whether intake is driven by milk production. Based on the energy intake regulation theory (Conrad et al., 1964; Mertens, 1987), intake is driven by milk production. For instance, the increase in DMI in cows treated with bST followed that of milk yield (Chalupa et al., 1986; Bauman, 1992), confirming that animals consume more $\mathrm{OM}$ to meet their energy requeriments. A positive relationship $(P<0.001)$ was also observed between DMI and $\mathrm{BW}^{0.75}(0.072 \pm 0.006 \mathrm{~kg}$ of DMI $/ \mathrm{kg}$ of $\left.\mathrm{BW}^{0.75}\right)$, likely in response to enhanced energy needs for maintenance.

The new model provided the most accurate and precise prediction of DMI (Table 3; Figure 1) compared with the 5 currently available DMI prediction models (Table 1). In fact, the DMI prediction model developed in the present meta-analysis explained $93.0 \%$ of the variation in DMI and yielded the lowest bias (mean overprediction of DMI $=0.11 \mathrm{~kg} / \mathrm{d})$ and RMSPE $(4.9 \%$ of observed DMI) and the largest proportion (95.0\%) of the random error in the RMSPE, indicating that most of the model error was not associated with fixed variables. In addition, the proposed model resulted in the highest precision $(\rho=0.97)$ and accuracy $\left(C_{\mathrm{b}}=\right.$ 0.99), reinforcing its robustness for predicting DMI of 

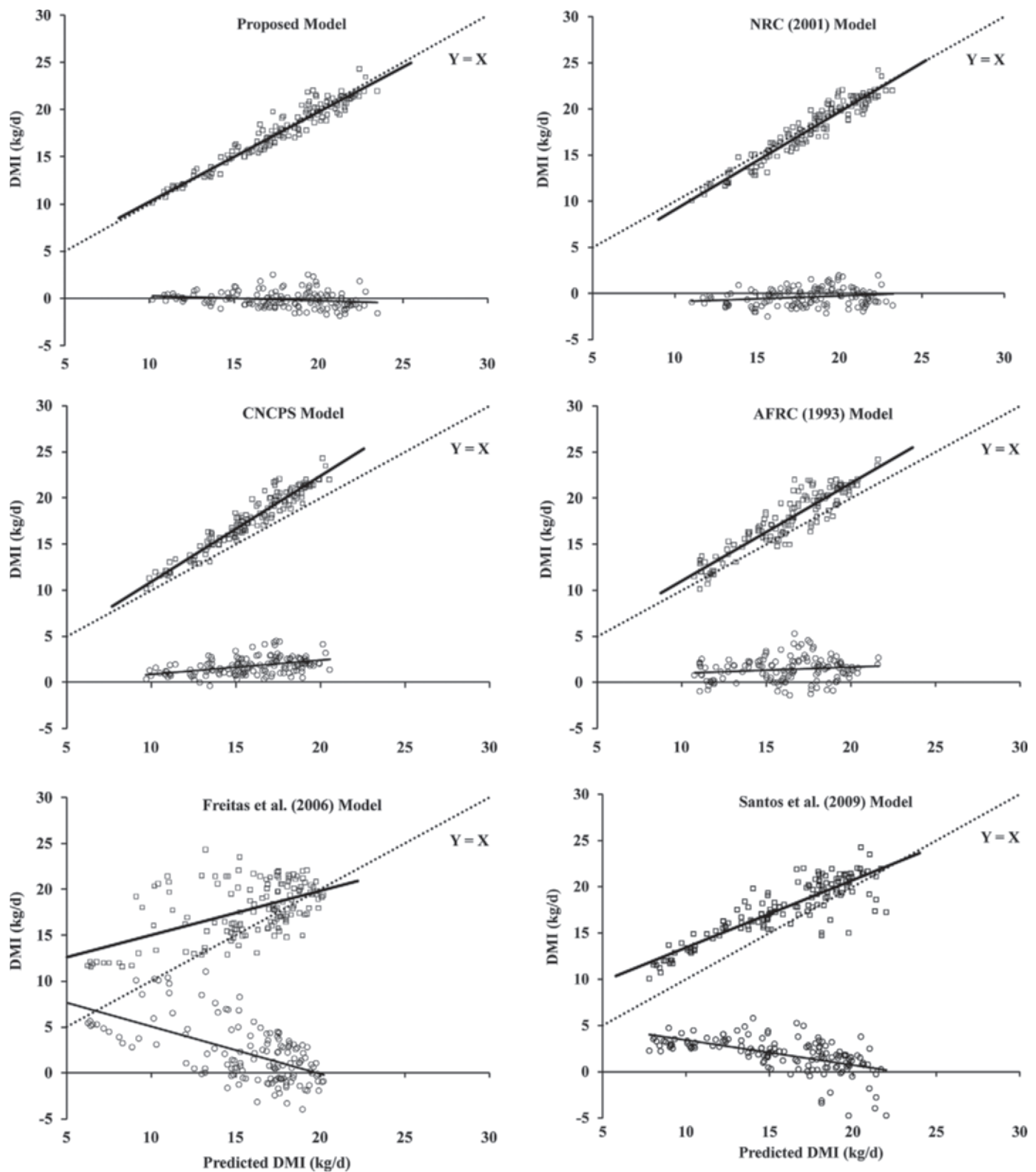

Figure 1. Relationship between observed $(\square)$ and residual (observed - predicted; $\bigcirc$ ) DMI with predicted values for dairy cows using the proposed model, NRC (2001), Agriculture and Food Research Council (AFRC, 1993; Vadivelloo and Holmes, 1979), Cornell Net Carbohydrate and Protein System (CNCPS, version 6.0; Tylutki et al., 2008), Freitas et al. (2006), and Santos et al. (2009) models. Data set included 148 treatment means from 40 studies. 
lactating dairy cows under the tropical conditions of Brazil.

The NRC (2001) model equation for predicting DMI explained $92.0 \%$ of the variation in DMI and overpredicted DMI by $0.41 \mathrm{~kg} / \mathrm{d}$. It also resulted in the second lowest RMSPE (5.8\% of the observed DMI) and second best precision $(\rho=0.94)$ and accuracy $\left(C_{\mathrm{b}}=0.98\right.$; Table 3; Figure 1). However, compared with the model proposed herein, the NRC (2001) equation resulted in greater dispersion of observed and residue values relative to the equality line ( $\mathrm{Y}=\mathrm{X}$; Figure 1). In contrast, only the NRC (2001) model and the model developed herein showed the same distribution between predicted and observed DMI values.

The better accuracy and precision of the new equation compared that of the NRC (2001) model for predicting DMI in lactating dairy cows raised under tropical conditions is likely explained by 2 major factors: (1) the data used for developing the new DMI prediction model were obtained from cows raised in the tropics; and (2) the use of study as a random effect in the model, which is known to improve predictions in biological systems and to provide a more accurate description of prediction errors (St-Pierre, 2001).

The CNCPS model (Tylutki et al., 2008) explained $93.0 \%$ of the variation in DMI but underpredicted it by $1.8 \mathrm{~kg} / \mathrm{d}$, with RMSPE of $11.3 \%$ of the observed DMI (Table 3). In addition, the error due to mean bias was relatively high (79.0\% of the MSPE). The CNCPS model uses the equation developed by Milligan et al. (1981) with adjustment for week of lactation (Roseler et al., 1997) for predicting DMI. Similar to the NRC (2001) model, the CNCPS model was developed using observations collected from US Holstein cows fed TMR, which could explain their higher biases compared with the proposed model. Thus, the differences in environmental and dietary conditions between Brazil and the United States limit the use of the NRC and CNCPS models to predict DMI under tropical conditions.

The AFRC (1993) model equation explained 85.0\% of the variation in DMI but underpredicted it by 1.4 $\mathrm{kg} / \mathrm{d}$; it was the third most accurate equation for predicting DMI, with RMSPE of $10.7 \%$ of the observed DMI and $\rho$ and $C_{\mathrm{b}}$ of 0.82 and 0.89 , respectively (Table $3)$. The mean bias error was the major component of the MSPE, averaging 56\%. The AFRC (1993) equation was based on Vadivello and Holmes (1979), who used 26 experiments with 385 cows fed grass silage-based diets in the United Kingdom. Thus, the differences in environmental and dietary conditions between Brazil and the United Kingdom limit the use of the AFRC equation to predict DMI under tropical conditions.

Although the models proposed by Freitas et al. (2006) and Santos et al. (2009) were developed using observations from lactating dairy cows raised in Brazil, the quality of their DMI predictions was poor. For instance, their equations explained 37.0 and $78.0 \%$ of the variation in DMI and underpredicted it by 2.31 and $1.88 \mathrm{~kg} / \mathrm{d}$, with RMSPE of 22.9 and $14.9 \%$ of the observed DMI, respectively. In addition, the precision $(\rho=0.49$ and 0.76$)$ and accuracy $\left(C_{\mathrm{b}}=0.81\right.$ and 0.86$)$ were lowest (Table 3; Figure 1) among the DMI prediction equations evaluated in the present study.

The poor precision and accuracy to predict DMI with the models proposed by Freitas et al. (2006) and Santos et al. (2009) might be related to the small number of studies used to develop the data sets. Freitas et al. (2006) used 9 experiments to build their empirical model to predict DMI in Holstein and Holstein $\times$ Zebu cows. Santos et al. (2009) reparameterized the NRC (2001) DMI prediction equation with data obtained from only 1 experiment, in which 18 Holstein $\times$ Zebu cows $(6$ Holstein $\times$ Gir, 6 Holstein $\times$ Guzera, and 6 Holstein $\times$ Nelore) were fed pasture supplemented with concentrate. Santos et al. (2009) concluded that the reparameterization of the NRC (2001) equation was appropriate to estimate DMI, but the accuracy and precision were not evaluated with an independent data set.

In conclusion, the DMI prediction model proposed in the present study: DMI $(\mathrm{kg} / \mathrm{d})=[0.4762 \times 4 \% \mathrm{FCM}$ $\left.(\mathrm{kg} / \mathrm{d})+0.07219 \times \mathrm{BW}(\mathrm{kg})^{0.75}\right] \times\left(1-e^{-0.03202 \times(\mathrm{DIM}+}\right.$ $24.9576 \pm 5.909)$ ] provided the highest accuracy and precision for predicting DMI in lactating dairy cows raised in the tropical conditions of Brazil compared with 5 currently available models (e.g.,NRC, 2001; CNCPS, Tylutki et al., 2008; AFRC, 1993; Freitas et al., 2006; and Santos et al., 2009).

\section{ACKNOWLEDGMENTS}

The authors thank Fundação de Amparo à Pesquisa do Estado de Mato Grosso (FAPEMAT, Cuiabá, Brazil; project number 483724/2011 PRONEM 006/2011), Coordenação de Aperfeçoamento de Pessoal de Nível Superior (CAPES, Brasília, Brazil) and Universidade Federal de Mato Grosso-Campus Sinop (Sinop, Brazil) for financial support. The authors also thank Normand R. St-Pierre (The Ohio State University, Columbus) for his valuable contributions and suggestions.

\section{REFERENCES}

AFRC (Agricultural and Food Research Council). 1993. Energy and Protein Requirements of Ruminants. CAB International, Wallingford, UK.

Bauman, D. E. 1992. Bovine somatotropin: Review of an emerging animal technology. J. Dairy Sci. 75:3432-3451.

Bibby, J. D., and H. Toutenburg. 1977. Prediction and Improved Estimation in Linear Models. John Wiley and Sons, Berlin, Germany. 
Chalupa, W., B. Vecchiarelli, A. E. Elser, D. S. Kronfeld, D. Sklan, and D. L. Palmquist. 1986. Ruminal fermentation in vivo as influenced by long-chain fatty acids. J. Dairy Sci. 69:1293-1301.

Conrad, H. R., A. D. Pratt, and J. W. Hibbs. 1964. Regulation of feed intake in dairy cows. 1. Change in importance of physical and physiological factors with increasing digestibility. J. Dairy Sci. 47:54-62.

Freitas, J. A., R. P. Lana, A. L. R. Magalhâes, and J. C. Souza. 2006. Prediction and validation of dairy cattle performance in brazilian conditions. Arch. Latinoam. Prod. Anim. 14:128-134.

Ingvartsen, K. L., and B. B. Andersen. 2000. Integration of metabolism and intake regulation: A review focusing on periparturient animals. J. Dairy Sci. 83:1573-1597.

King, T. S., and V. M. Chinchilli. 2001. Robust estimator of the concordance correlation coefficient. J. Biopharm. Stat. 11:83-105.

Kolmogoroff, A. N., 1933. Sulla determinazione empirica di una legge di distribuzione. Giornale dell'Istituto Italiano degli Attuari 4:83-91.

Liao, J. J. Z. 2003. An improved concordance correlation coefficient. Pharm. Stat. 2:253-261.

Lin, L. I. K. 1989. A concordance correlation coefficient to evaluate reproducibility. Biometrics 45:255-268.

Littell, R. C. G. A., W. W. Milliken, R. D. Stroup, R. D. Wolfinger, and O. Schabenberger. 2006. SAS for Mixed Models. 2nd ed. SAS Institute Inc., Cary, NC.

Mertens, D. R. 1987. Predicting intake and digestibility using mathematical models of ruminal function. J. Anim. Sci. 64:1548-1558.

Milligan, R. A., L. E. Chase, C. J. Sniffen, and W. A. Knoblauch. 1981. Least-cost balanced dairy rations. Anim.Sci. Mimeo No. 54. Cornell University, Ithaca, NY.

NRC (National Research Council). 2001. Nutrient Requirements of Dairy Cattle. 7th rev. ed. Natl. Acad. Sci., Washington, DC.

Neter, J., M. H. Kutner, C. J. Nachtsheim, and W. Wasserman. 1996. Applied Linear Statistical Models. 4th ed. McGraw-Hill, New York, NY.

Oliveira, A. S., D. N. F. V. Cunha, J. M. S. Campos, S. M. L. R. Vale, and A. J. Assis. 2007. Identification and quantification of reference systems milk production. R. Bras. Zootec. 36:507-516.

Roseler, D. K., D. G. Fox, L. E. Chase, A. N. Pell, and W. C. Stone 1997. Development and evaluation of equations for prediction of feed intake for lactating Holstein dairy cows. J. Dairy Sci. 80:878-893.

Santos, S. A., S. C. Valadares Filho, J. R. M. Ruas, D. S. Pina, A. S. Oliveira, and P. M. Amaral. 2009. Prediction of pasture dry matter intake by F1 Hostein $\times$ Zebu dairy cows using the structure of NRC (2001) prediction model. Abstract e-547 in Proc. 47th Reunião Anual da Sociedade Brasileira De Zootecnia, Maringá, DF, Brazil. Sociedade Brasileira de Zootecnia, Brasília, Brazil. (CD-ROM).

Sauvant, D., P. Scmidely, J. J. Daudin, and N. R. St-Pierre. 2008. Meta-analyses of experimental data: Application in animal nutrition. Animal 2:1203-1214.

Smirnov, N. 1933. Estimate of deviation between empirical distribution functions in two independent samples. Moscow Univ. Math. Bull. 2:3-16.

St-Pierre, N. R. 2001. Invited review: Integrating quantitative findings from multiple studies using mixed model methodology. J. Dairy Sci. 84:741-755.

Stock, L. A., A. V. Carneiro, G. R. Carvalho, R. Zoccal, P. C. Martins, and L. C. T. Yamaguchi. 2007. Brazilian milk production systems and its representativeness. Accessed May 27, 2013. http:// www.cileite.com.br/sites/default/files/sistemas_de_producao_e_ sua_representatividade_na_producao_de_leite_no_brasil.pdf.

Tedeschi, L. O. 2006. Assessment of the adequacy of mathematical models. Agric. Syst. 89:225-247.

Tylutki, T. P., D. G. Fox, V. M. Durbal, L. O. Tedeschi, J. B. Russell, M. E. Van Amburgh, T. R. Overton, L. E. Chase, and A. N. Pell. 2008. Cornell Net Carbohydrate and Protein System: A model for precision feeding of dairy cattle. Anim. Feed Sci. Technol. $143: 174-202$
Vadivello, J., and W. Holmes. 1979. The prediction of the voluntary feed intake of dairy cows. J. Agric. Sci. (Camb.) 93:553-562.

Vyas, D., and R. A. Erdman. 2009. Meta-analysis of milk protein yield responses to lysine and methionine supplementation. J. Dairy Sci. 92:5011-5018.

West, J. W. 2003. Effects of heat-stress on production in dairy cattle. J. Dairy Sci. 86:2131-2144.

\section{Appendix 1: List of Publications Describing the Experiments Used in the Development Model}

Albuquerque, S. S. C., M. A. Lira, M. V. F. Santos, J. C. B. Dubeux Júnior, and J. N. M. I. Farias. 2002. Utilization of three nitrogen sources associated to cactus forage (Opuntia ficus-indica, Mill.) cv. Gigante in dairy cows supplementation grazing at differed pasture. R. Bras. Zootec. 31:1315-1324.

Alves, A. F., J. T. Zervoudakis, L. K. Hatamoto-Zervoudakis, L. S. Cabral, F. P. Leonel, and N. F. Paula. 2010. Replacing soybean meal with high energy cottonseed meal in diets for dairy yielding cows: Intake, nutrient digestibility, nitrogen efficiency and milk yield. R. Bras. Zootec. 39:532-540.

Amaral, R. C. 2011. Strategies to control top losses in corn silage and the nutritive value responses in Holstein cows. MS Thesis. Superior School of Agriculture "Luiz de Queiroz", Piracicaba, Brazil.

Aquino, A. A., B. G. Botari, F. S. Ikeda, P. H. M. Rodrigues, M. F. Martins, and M. V. Santos. 2007. Effect of increasing dietary urea levels on milk yield and composition of lactating cows. R. Bras. Zootec. 36:881-887.

Araújo, P. R. B., M. A. Ferreira, L. H. A. Brasil, D. C. Santos, R. M. B. Lima, A. S. C. Véras, M. V. F. Santos, S. V. Bispo, and M. Azevedo. 2004. Replacement of corn by forage cactus in the total mixed rations for crossbreed lactating cows. R. Bras. Zootec. $33: 1850-1857$.

Assis, A. J. 2005. Soyhulls and cottonhulls on feeding of dairy cows. $\mathrm{PhD}$ Thesis. University Federal of Viçosa, Viçosa, Brazil.

Assis, A. J., J. M. S. Campos, S. C. Valadares Filho, A. C. Queiroz, R. P. Lana, R. F. Euclydes, J. M. Neto, A. L. R. Magalhães, and S. S. Mendonça. 2004. Citrus pulp in diets for milking cows. 1. intake of nutrients, milk production and composition. R. Bras. Zootec. 33:242-250.

Barletta, R. V. 2010. Whole and raw soybean in feeding of dairy cows. MS Diss. University of São Paulo, Pirassununga, Brazil.

Benedetti, E., N. M. Rodriguez, W. E. Campos, A. L. C. C. Borges, and E. S. Saliba. 2008. Fed intake and milk production of HolsteinZebu crossbreed cows hold in different tropical pastures. Anim. Sci. Bras. 9:578-589.

Bitencourt, L. L., J. R. M. Silva, B. M. L. Oliveira, G. S. Dias Júnior, F. L. Siécola Júnior, O. F. Zacaroni, and M. N. Pereira. 2011. Diet digestibility and performance of dairy cows supplemented with live yeast. Scientia Agricola (Piracicaba, Brazil) 68:301-307.

Calomeni, G. D. 2011. Use of polymer-coated slow-relase urea on feeding dairy cows. MS Diss. University of São Paulo, Pirassununga, Brazil.

Chagas, L. J. 2011. Protein levels in the concentrate for early lactation cows maintained in an elephant grass pasture. MS Diss. Superior School of Agriculture "Luiz de Queiroz", Piracicaba, Brazil.

Cobianchi, J. V., A. S. Oliveira, J. M. S. Campos, A. V. Guimarães, S. C. Valadares Filho, F. P. Cobianchi, and T. E. S. Oliveira. 2012. Productive performace and effciency of utilion of the diet components in dairy cows fed castor meal treated eith calccium oxide. R. Bras. Zootec. 41:2238-2248.

Cordeiro, C. F. A., M. L. A. Pereira, S. S. Mendonça, P. J. P. Almeida, L. V. Aguiar, and M. P. Figueiredo. 2007. Intake and total digestibility of nutrients and milk production and composition in dairy cows fed with increasing crude protein levels in the diet with sugar cane and concentrates. R. Bras. Zootec. 36:2118-2126.

Corrêia, C. E. S., M. N. Pereira, S. G. Oliveira, and M. H. Ramos. 2003. Performance of Holstein cows fed sugarcane or corn silages of different grain textures. Scientia Agricola (Piracicaba, Brazil) 60:621-629. 
Costa, L. T., F. F. Silva, C. M. Veloso, A. J. V. Pires, A. L. Rocha Neto, F.B. L. Mendes, E. S. O. Rodrigues, and V. L. Silva. 2011. Economical analysis of different concentrate levels for dairy crossbred fed sugar cane based diets. R. Bras. Zootec. 40:1155-1162.

Costa, M. G. 2008. Rations with different sources of fat for lactating dairy cows. MS Thesis. University Federal of Viçosa, Viçosa, Brazil.

Costa, M. G., J. M. S. Campos, S. C. Valadares Filho, R. F. D. Valadares, S. S. Mendonça, D. P. Souza, and M. P. Teixeira. 2005. Effects of feeding corn silage or different dietary ratios of sugarcane and concentrate on production of lactating dairy cows. R. Bras. Zootec. 34:2437-2445.

D'Angelo, L. S. 2009. Fat sources fed to dairy cows in transition period and early lactation. MS Diss. University of São Paulo, Pirassununga, Brazil.

Deresz, F., A. M. Fernandes, L. L. Matos, and J. C. Teixeira. 1996. Whole soybean utilization on the concentrate for high producing dairy cows. R. Bras. Zootec. 25:113-124.

Dias Júnior, G. S. 2011. Performance of dairy cows supplemented with calcium salt rich in linoleic acid or roasted soybean. MS Diss. University Federal de Lavras, Lavras, Brazil.

Eifert, E. C., R. P. Lana, D. P. D. Lanna, P. B. Arcuri, M. I. Leão, S C. Valadares Filho, W. M. Leopoldino, and J. H. S. Silva. 2005. Effects of Dietary Supplementation of Monensin and Soybean Oil on Production of Early Lactating Dairy Cows. R. Bras. Zootec. 34:2123-2132

Eifert, E. C., R. P. Lana, D. P. D. Lanna, W. M. Leopoldino, M. V. M. Oliveira, P. B. Arcuri, J. M. S. Campos, M. I. Leão, and S. C. Valadares Filho. 2006. Effects of different carbohydrates sources and soybean oil on intake, milk yield, and milk composition of lactating dairy cows. R. Bras. Zootec. 35:211-218.

Elyas, A. C. W., P. C. A. Paiva, F. C. F. Lopes, D. Vilela, P. B. Arcuri, and M. J. Morenz. 2009. Evaluation of the cornell net carbohydrate and protein system on the prediction of dry matter intake of grazing lactating Holstein cows. R. Bras. Zootec. 38:1096-1103.

Freitas Júnior, J. E. 2012. Fat sources in the diet of cows on lactation. MS Thesis. University Estadual Paulista - Júlio de Mesquita Filho., Jaboticabal, Brazil

Fukumoto, N. M., J. C. Damasceno, F. Deresz, C. E. Martins, A. C Cóser, and G. T. Santos. 2010. Milk yield and composition, feed intake and stocking rate of crossbread cows in tropical grasses managed in a rotational grazing system. R. Bras. Zootec. 39:15481557.

Gandra, J. R. 2009. Evaluation of use of sodic monensin in dairy cows rations: Productive performance and milk residues. MS Dissertation. University of São Paulo., Pirassununga, Brazil.

Geron, L. J. V., L. M. Zeoula, J. A. Erkel, I. N. Prado, E. Bublitz, and O. P. P. Prado. 2010. Intake, nutrient digestibility, milk production and composition of cows fed brewery residue fermented. Acta Scientiarum Anim. Sci. 32:69-76.

Gomide, J. A., I. J. Wendling, S. P. Bras, and H. B. Quadros. 2001 Milk production and herbage intake of crossbred Holstein $\times$ Zebu cows grazing a Brachiaria decumbens pasture under two daily forage allowances. R. Bras. Zootec. 30:1194-1199.

Imaizumi, H., F. A. P. Santos, A. V. Pires, and S. O. Juchem. 2006 Protein and starch sources varying in rumen degradability to feed dairy cows. Pesq. Agropec. Bras. 41:1413-1420.

Jobim, C. C., G. A. Ferreira, G. T. Santos, U. Cecato, and J. C. Damasceno. 2002. Milk production and composition of Holstein cows fed with alfafa and Tifton-85 hays and corn silage. Acta Scientiarum Anim. Sci. 24:1039-1043.

Leggi, T. C. S. S., G. T. Santos, A. C. Furlan, E. S. Sakaguti, N. P Ribas, R. R. Mira, D. R. Veiga, and V. Bett. 1998. Use of canola meal (Brassica napus)in the dairy cows feeding. R. Bras. Zootec. $27: 770-776$.

Lima, M. L. P., T. T. Berchielli, J. R. Nogueira, A. C. Ruggieri, L. J. M. Aroeira, A. K. D. Salman, and J. P. G. Soares. 2001. Estimation of voluntary intake of tanzania grass (Panicum maximum, Jacq. cv. Tanzania) rotationally grazed by lactating cows. R. Bras. Zootec. 30:1919-1924.

\section{Appendix 2: List of Publications Describing the Experiments Used in the Evaluation Models}

Lopes, F. C. F., L. J. M. Aroeira, N. M. Rodriguez, I. B. M. Sampaio, F. Deresz, I. Borges, and T. T. Berchielli. 2005. Prediction of the voluntary intake of elephantgrass (Pennisetum purpureum, Schumack) grazing by Holstein $\times$ Zebu lactating dairy cows. $R$. Bras. Zootec. 34:1017-1028.

Macedo, F. L. 2012. Levels of concentrate with or without inert fat for lactating dairy cows grazing tropical pastures. MS Diss. Superior School of Agriculture "Luiz de Queiroz", Piracicaba, Brazil.

Magalhães, A. L. R., J. M. S. Campos, S. C. Valadares Filho, R. A. Torres, J. M. Neto, and A. J. Assis. 2004. Sugar cane as a substitute for corn silage in diets for milking cows. Performance and economical viability. R. Bras. Zootec. 33:1292-1302.

Magalhães, A. L. R., K. Zorzi, A. C. Queiroz, R. Mello, E. Detmann, and J. C. Pereira. 2008. Residue from common bean (Phaseolus vulgaris L.) processing in the rations for milking cows: Intake, digestibility, milk production and composition and feeding efficiency. R. Bras. Zootec. 37:529-537.

Magalhães, M. C. S., A. S. C. Véras, M. A. Ferreira, F. F. R. Carvalho, P. R. Cecon, J. N. Melo, W. S. Melo, and J. T. Pereira. 2004 Broiler litter in forage cactus based diets (Opuntia ficus-indica Mill) for lactating crossbred cows. 1. Nutrients intake and milk yield. R. Bras. Zootec. 33:1897-1908.

Magalhães, V. J. A., and P. H. M. Rodrigues. 2003. Performance of lactating dairy cows fed alfalfa haylage with microbial inoculant. R. Bras. Zootec. 32:2016-2022.

Malafaia, P. A. M., S. C. Valadares Filho, J. F. C. Silva, M. I. Leão, J. C. Pereira, R. A. M. Vieira, and F. N. Matos. 1996. Bovine tallow in rations for lacting cows. 1. Nutrient intake, milk yield and composition. R. Bras. Zootec. 25:153-163.

Martins, S. C. S. G., V. R. Rocha-Júnior, L. A. Caldeira, D. A. A. Pires, I. C. Barros, E. C. J. Sales, C. C. R. Santos, A. C. R. Aguiar, and C. R. Oliveira. 2011. Intake, digestibility, milk production and economic analysis of diets with different forages. Rev. Bras. Saúde Prod. Anim. 12:691-708.

Maturana Filho, M. 2009. Productive and reproductive performance and blood parameters of dairy cows feeding with diferente fat sources in trasition period and early lactation. MS Diss. University of São Paulo, Pirassununga, Brazil.

Melo, A. A. S., M. A. Ferreira, A. S. C. Véras, M. A. Lira, L. E. Lima, R. A. S. Pessoa, S. V. Bispo, A. M. D. Cabral, and M. Azevedo. 2006. Dairy cows performance fed whole cottonseed in a forage of cactus-base diet. Pesq. Agropec. Bras. 41:1165-1171.

Mendonça, S. S., J. M. S. Campos, S. C. Valadares Filho, R. F. D Valadares, C. A. S. R. P. Lana, A. C. Queiroz, A. J. Assis, and M. L. A. Pereira. 2004. Intake, apparent digestibility, milk production and composition and ruminal variables of dairy cows fed sugar cane based diets. R. Bras. Zootec. 33:481-492.

Mora, P. J. G., M. I. Leão, S. C. Valadares Filho, J. F. C. Silva, P. A. M. Malafaia, and R. A. M. Vieira. 1996. Soybean seeds in rations for lactating dairy cows: Nutrient intake, milk production and composition. R. Bras. Zootec. 25:369-381.

Moreira, A. L., O. G. Pereira, R. Garcia, S. C. Valadares Filho, J. M. S. Campos, V. G. Souza, and J. T. Zervoudakis. 2001. Milk yield, intake and apparent digestibility of nutrients, $\mathrm{pH}$ and ruminal ammonia concentration in lactating cow fed diets containing corn silage and alfalfa and coastcross bermudagrass hays. R. Bras. Zootec. 30:1089-1098.

Moreira, J. N., M. A. Lira, M. V. F. Santos, M. A. Ferreira, and A. A S. Melo. 2007. Substitution of soybean to urea in the supplementation of milk cows in the sertao of Pernambuco. Revista Caatinga 20:30-37.

Nascimento, W. G., I. N. Prado, C. C. Jobim, J. C. Emile, F. Surault, and C. Huyghe. 2008. Feeding value of corn silage and sorghum and its influence on performance of dairy cows. R. Bras. Zootec. $37: 896-904$

Neves Neto, J. T. 2009. Performance and ruminal parameters of dairy cows fed silage cane sugar and not nitrgenio protein sources of and 
energy in the concentrate. MS Diss. Superior School of Agriculture "Luiz de Queiroz", Piracicaba, Brazil.

Oliveira, A. S., J. M. S. Campos, S. C. Valadares Filho, A. J. Assis, R. M. A. Teixeira, R. F. D. Valadares, D. S. Pina, and G. S. Oliveira. 2007. Replacing corn with coffee hulls or soyhulls in dairy cows diets: Intake, nutrient digestibility, and milk production and composition. R. Bras. Zootec. 36:1172-1182.

Oliveira, A. S., J. M. S. Campos, E. P. Viana, D. S. Caixeta, S. C. Valadares Filho, A. M. F. Santiago, J. P. Carmo, A. C. S. Souza, G. H. Soares, J. P. Giordani, and L. F. Lago. 2010. Intake, digestibility, and productive performance of dairy cows fed with sunflower meal. J. Dairy Sci. 93(E-Suppl. 1):448. (Abstr.)

Oliveira, A. S., R. F. D. Valadares, S. C. Valadares Filho, P. R. Cecon, G. A. Oliveira, R. M. N. Silva, and M. A. L. Costa. 2001. Intake, apparent digestibility, milk composition and production of lactating cows fed four non protein nitrogen compounds levels. R. Bras. Zootec. 30:1358-1366.

Oliveira, S. G. 2001. Utilization of sources of fat in diets containing different levels of fiber for lactating cow. MS Diss. Superior School of Agriculture "Luiz de Queiroz", Piracicaba, Brazil.

Oliveira, T. S., J. C. Pereira, A. C. Queiroz, P. R. Cecon, and M. V. Santos. 2011. Yield performance of cows fed diets with elephant grass subjected to different fertilization and concentrate levels. Revista Ceres 58:452-461.

Oliveira, V. S., M. A. Ferreira, A. Guim, E. C. Modesto, B. L. Arnaud, and F. M. Silva. 2007. Effects of replacing corn and Tifton hay with forage cactus on milk production and composition of lactating dairy cows. R. Bras. Zootec. 36:928-935.

Paiva, J. A. J., H. A. Moreira, G. M. Cruz, and R. S. Vemeque. 1991. Sugar cane-based diet associated with urea/ammonium sulfate as exclusive forage for milking cows. R. Bras. Zootec. 20:90-99.

Paiva, V. R. 2009. Levels of crude protein in diets for dairy Holstein cows in tie stall. MS Diss. University Federal of Viçosa, Viçosa, Brazil.

Pedroso, A. M., F. A. P. Santos, C. M. M. Bittar, A. V. Pires, and J. C. Martinz. 2007. Replacement of ground corn by soybean hulls in the diets for confined lactating cows. R. Bras. Zootec. 36:1651-1657.

Pereira, C. M. A., J. F. C. Silva, S. C. Valadares Filho, J. M. S. Campos, and P. R. Cecon. 1998. Soy bean ground in cow ration on lactation. I. Intake and digestibility nutrients. R. Bras. Zootec. $27: 1218-1224$

Pereira, C. M. A., J. F. C. Silva, S. C. Valadares Filho, J. M. S. Campos, and P. R. Cecon. 1998. Soy bean ground in cow ration on lactation. II. Milk production and composition. R. Bras. Zootec. $27: 1225-1233$

Pereira, M. L. A., S. C. Valadares Filho, R. F. D. Valadares, J. M. S. Campos, M. I. Leão, C. A. R. Pereira, D. S. Pina, and S. S. Mendonça. 2005. Intake, total apparent digestibility, milk production and composition in early lactation cows fed with increasing levels of crude protein in the concentrate. R. Bras. Zootec. 34:1029 1039.

Pereira, M. L. A., S. C. Valadares Filho, R. F. D. Valadares, J. M. S. Campos, M. I. Leão, C. A. R. Pereira, P. A. Silva, and S. S. Mendonça. 2005. Intake, total apparent digestibility, milk production and composition in mid lactation cows fed with increasing levels of crude protein in the concentrate. R. Bras. Zootec. 34:1040-1050.

Peres Neto, D., A. A. Rodrigues, F. S. Wechsler, R. P. Ferreira, F. C. Mendonça, and A. R. Freitas. 2011. Performance of dairy cows on alfalfa pasture supplemented with corn silage and concentrate and its economic viability. Arq. Bras. Med. Vet. Zootec. 63:399-407.

Pimentel, P. G., A. A. A. N. Moura, J. N. M. Neiva, A. A. Araújo, and R. F. L. Tair. 2007. Dry mater intake, milk yield, and heat stress indicators of dairy cows fed diets with cashew nut. Arq. Bras. Med. Vet. Zootec. 59:1523-1530.

Pina, D. S., S. C. Valadares Filho, R. F. D. Valadares, J. M. S. Campos, E. Detmann, M. I. Marcondes, A. S. Oliveira, and R. M. A. Teixeira. 2006. Intake, apparent total tract digestibility of nutrients, and milk yield and composition of dairy cows fed diets supplemented with different protein sources. R. Bras. Zootec. 35:1543-1551.
Porto, P. P., F. Deresz, G. T. Santos, F. C. F. Lopes, U. Cecato, and A. C. Cóser. 2009. Milk production, milk composition, intake and digestibility of tropical forages under intermittent grazing system. R. Bras. Zootec. 38:1422-1431.

Ramalho, R. P., M. A. Ferreira, A. S. C. Véras, L. E. Lima, and V. R. R. A. Rocha. 2006. Replacement of corn with cassava scrapings in diets for primiparous lactating Holstein cows. R. Bras. Zootec. 35:1221-1227.

Rangel, A. H. N. 2005. Sugar-cane in the feeding of dairy cows and growing heifers. MS Thesis. University Federal of Viçosa, Viçosa, Brazil.

Rêgo, A. C. 2012. Millet and corn silage in diet of dairy cows. MS Thesis. University Estadual Paulista-Júlio de Mesquita Filho, Jaboticabal, Brazil.

Ribeiro Filho, H. M. N., C. D. Giacomet, K. M. Dias, S. Crestani, E. A. Setelich, and A. Thaler Neto. 2009. Corn gluten meal to dairy cows grazing Italian ryegrass. Sci. Rural. 39:1173-1179.

Rocha, F. C., R. Garcia, A. W. P. Freitas, A. L. Souza, K. F. Gobbi, S. C. Valadares Filho, R. G. Tonuccis, and G. C. Rocha. 2006. Coffee hulls in diets of lactating dairy cows: Intake, digestibility and milk yield and composition. R. Bras. Zootec. 35:2163-2171.

Salvador, S. C., M. N. Pereira, J. F. Santos, L. Q. Melo, and M. L. Chaves. 2008. Response of lactating cows to the total replacement of corn by citrus pulp and to the supplementation of organic trace minerals. I: Intake and digestion. Arq. Bras. Med. Vet. Zootec. 60:682-690.

Salvador, S. C.. M. N. Pereira, J. F. Santos, L. Q. Melo, and M. L. Chaves. 2008. Response of lactating cows to the total replacement of corn by citrus pulp and to the supplementation of organic trace minerals. II: Performance and savings. Arq. Bras. Med. Vet. Zootec. 60:1142-1149.

Santana Júnior, H. A., M. P. Figueiredo, E. O. Cardoso, F. B. L. Mendes, G. Abreu Filho, A. A. Pinheiro, P. T. Viana, and J. P. S. Roseira. 2013. Crude glycerin in supplement to primiparous lactating cows grazing on tropical pasture: nutritional and productive characteristics. R. Bras. Zootec. 42:117-124.

Santiago, A. M. F., J. M. S. Campos, A. S. Oliveira, S. C. Valadares Filho, S. A. Santos, S. M. Souza, and I. F. Santiago. 2013. Urea in sugarcane-based diets for dairy cows. R. Bras. Zootec. 42:456462.

Santos, A. B., M. L. A. Pereira, S. T. Azevedo, R. D. Signoretti, G. R. Siqueira, S. S. Mendonça, A. J. V. Pires, T. C. J. Pereira, P. J. P. Almeida, L. S. O. Ribeiro, and C. A. R. Pereira. 2012. Lactating cows fed with silage of sugar cane with and without additive bacteria: Intake, digestibility, milk production and composition. Rev. Bras. Saúde. Prod. Anim. 13:720-731.

Santos, A. D. F., C. A. A. Torres, F. P. Rennó, M. R. S. Drumond, and J. E. Freitas Junior. 2009. Use of soybean oil for dairy cows during transition period: Intake, milk yield and composition. $\mathrm{R}$. Bras. Zootec. 38:1363-1371.

Santos, F. A., C. A. Carmo, J. C. Martinez, A. V. Pires, and C. M. M. Bittar. 2006. Supplementing yeast culture (Saccharomyces cerevisiae) for late lactating dairy cows fed diets varying in starch content. R. Bras. Zootec. 35:1568-1575.

Santos, M. V. F., I. Farias, M. A. Lira, M. M. A. Nascimento, D. C. Santos, and J. J. Tavares Filho. 1998. Harvest of the forage cactus (Opuntia ficus indica Mill) cv. Giant on the performance of lactating cows. R. Bras. Zootec. 27:33-39.

Santos, S. A. 2011. Intake and lactation curves of F1 Holstein $\times$ Zebu dairy cows in pasture and feedlot. MS Thesis. University Federal of Viçosa, Viçosa, Brazil.

Silva, A. E. V. N., A. Guim, M. A. Ferreira, L. E. Lima, R. A. S. Pessoa, and M. Y. Sosa. 2005. Feeding strategies for diet based on forage cactus on the performance and digestibility in cows in late lactation. Acta Sci. Anim. 27:269-276.

Silva, B. O., L. A. Leite, M. I. C. Ferreira, L. M. Fonseca, and R. B. Reis. 2004. Sunflower silage and corn silage in lactating cow diets: Milk production and composition. Arq. Bras. Med. Vet. Zootec. $56: 750-756$.

Silva, C. J. 2012. Processing of corn grain for use in feeding of dairy cows. MS Thesis. University Federal of Viçosa, Viçosa, Brazil. 
Silva, C. V., R. P. Lana, J. M. S. Campos, A. C. Queiroz, M. I. Leão, and D. C. Abreu. 2009. Intake, apparent nutrient digestibility and performance of milking cows under pasture as a function of levels of concentrate and crude protein in the diet. R. Bras. Zootec. $38: 1372-1380$

Silva, J. C. P. M. 2009. Levels of concentrate and rumen undegradable protein in the diet of lactating cows. MS Thesis. University Federal of Viçosa, Viçosa, Brazil.

Silva, J. G. M., D. S. Silva, M. A. Ferreira, G. F. C. Lima, A. A. S. Melo, and M. C. N. M. Diniz. 2005. Replacement of sorghum silage (Sorghum bicolor L. Moench) with a columnar cactus (Pilosocereus gounellei (A. Weber ex K. Schum.) Byl ex Rowl.) on diets of lactating dairy cows. R. Bras. Zootec. 34:1408-1417.

Silva, R. M. N., R. F. D. Valadares, S. C. Valadares Filho, P. R. Cecon, J. M. S. Campos, G. A. Oliveira, and A. S. Oliveira. 2001. Urea for dairy cows. 1. Intake, digestibility, milk production and composition. R. Bras. Zootec. 30:1639-1649.

Soares, C. A., J. M. S. Campos, S. C. Valadares Filho, R. F. D. Valadares, S. S. Mendonça, A. C. Queiroz, and R. P. Lana. 2004. Intake, apparent digestibility, milk production and composition in dairy cows fed with wheat middlings. R. Bras. Zootec. 33:21612169.

Sobreira, H. F. 2011. Residues of macauba coconut in partial replacement of corn and soybean meal in concentrate for milking crossbred. MS Diss. University Federal of Viçosa, Viçosa, Brazil.

Souza, A. L., R. Garcia, S. C. Valadares Filho, F. C. Rocha, J. M. S. Campos, L. S. Cabral, and K. F. Gobbi. 2005. Effects of feeding coffee hulls on intake, digestibility and milk yield and composition of lactating dairy cows. R. Bras. Zootec. 34:2496-2504.

Souza, D. P., J. M. S. Campos, S. C. Valadares Filho, R. P. Lana, C. A. Z. Sediyama, and J. Mendes Neto. 2009. Feeding behavior, feed intake and digestibility, milk composition and production of cows fed maize silage or sugarcane with whole cottonseed. R. Bras. Zootec. 38:2053-2062.

Souza, J. G. 2012. Performance and efficiency of nutrient utilization of grazing dairy cows supplemented with expeller meal Jatropha curcas L. treated with sodium hydroxide. MS Thesis. University Federal of Mato Grosso, Cuiaba, Brazil.

Souza, S. M. 2011. Performance and milk fatty acid composition of dairy cows fed sugar cane-based diets containing increasing levels of sunflower oil. MS Thesis. University Federal of Viçosa, Viçosa, Brazil.

Stelzer, F. S., R. P. Lana, J. M. S. Campos, A. B. Mancio, J. C. Pereira, and J. G. Lima. 2009. Performance of milking cows fed concentrate at different levels associated or not with própolis. $\mathrm{R}$ Bras. Zootec. 38:1381-1389.

Teixeira, R. M. A., R. P. Lana, L. O. Fernandes, A. S. Oliveira, A. C. Queiroz, and J. J. O. Pimentel. 2010. Productive performance of dairy Gyr cows in feedlot fed levels of concentrate and crude protein in diets. R. Bras. Zootec. 39:2527-2534.

Vargas, L. I. M. 2011. Levels of energetic and protein concentrate in diets of milking cows. MS Diss. University Federal of Viçosa, Viçosa, Brazil.

Vilela, M. S., M. A. Ferreira, A. S. C. Véras, M. V. F. Santos, I Farias, A. A. S. Melo, R. P. Ramalho, and P. R. B. Araújo. 2003. Evaluation of different supplements for lactating crossbred cows fed sugarcane: Performance and digestibility. R. Bras. Zootec. 32:768-777.

Vito, E. S. 2010. Crude glycerin in feed for dairy cows. MS Diss. University Federal of Viçosa, Viçosa, Brazil.

Wanderley, W. L., M. A. Ferreira, D. K. B. Andrade, A. S. C. Véras, I. Farias, L. E. Lima, and A. M. A. Dias. 2002. Replacement of forage cactus (Opuntia ficus indica Mill) for sorghum silage (Sorghum bicolor (L.) Moench) in the dairy cows feeding. R. Bras. Zootec. $31: 273-281$.

Wernersbach Filho, H. L., J. M. S. Campos, A. J. Assis, S. C. Valadares Filho, A. C. Queiroz, R. F. D. Valadares, and R. P. Lana. 2006. Intake, apparent digestibility, and production of dairy cows fed concentrate processed in different forms. R. Bras. Zootec. $35: 1228-1235$ 